\title{
1. ACKNOWLEDGEMENTS, INTRODUCTION, AND EXPLANATORY NOTES: THE JAPAN TRENCH TRANSECT, LEGS 56 AND 57, DEEP SEA DRILLING PROJECT
}

\author{
Michael A. Arthur ${ }^{1}$ and Charles G. Adelseck, Jr., Scripps Institution of Oceanography, La Jolla, California
}

\section{ACKNOWLEDGMENTS}

The scientific parties of Legs 56 and 57 gratefully acknowledge the assistance of many persons who gave invaluable help to make the outcome of drilling on the Japan Trench Transect a significant scientific contribution. The efforts of Capt. Clarke, Capt. Dill, and their crews and of the drilling crews often went beyond those of normal duty-especially in rough sea conditions that made operations very difficult; these efforts are sincerely appreciated. The long hours and difficult decisions required of the operations manager never dampened their enthusiasm for achieving each scientific objective; we appreciate the efforts of Bob Knapp, Glen Foss, Mike Lehman, and Richard Meyers, the laboratory officers, and of their technicians, who performed the numerous tasks necessary to accomplish the Japan Trench Transect objectives and were fine shipmates.

In the Japanese scientific community, the constant support of Dr. Yasufumi Ishiwada, Vice-President for Research, Japan Petroleum Development Corporation (presently Japan National Oil Corporation, JNOC), was instrumental in identifying the primary sites, and his advice after the cruise on various scientific questions has been invaluable. We are grateful for the cooperation and assistance of the IPOD-Japanese scientific community, the Ocean Research Institute of the University of Tokyo, and the Department of Education, Science and Culture. We also wish to extend our gratitude to Drs. Akira Matsuzawa, Akira Kujiraoka, and Yasufumi Ishiwada of Japan National Oil Corporation for the use of the multichannel records off the Sanriku Coast. Furthermore, we are grateful to Dr. Toshiro Tamano and his colleagues of Japan Petroleum Exploration Co. (JAPEX) for collecting and processing the multichannel data. And lastly, the support and enthusiasm of our many Japanese colleagues on shore, who saw us off to sea and greeted us on our return, will long be remembered.

\section{INTRODUCTION}

The Japan Trench area was identified three years ago as a favorable place for studying convergent margins during the initial deliberations of the IPOD Active Margins Panel. Between then and now, various institutions and agencies in Japan surveyed the trench area and provided a wealth of geophysical and conventional sampling data in addition to the scientific investigations in prog-

\footnotetext{
${ }^{1}$ Currently at U.S. Geological Survey, Denver, Colorado.
}

ress and the relatively complete background series of studies reported. Some studies had also been reported by U. S. investigators. The Japan Trench area had been investigated mainly by the Japanese Hydrographic Office and the Meteorological Agencies and also by the Ocean Research Institute of the University of Tokyo (ORI). After joining IPOD, the Ocean Research Institute of the University of Tokyo, the Japanese Hydrographic Office and the Geological Survey of Japan made surveys in this area as part of their ongoing program and also as part of the IPOD predrilling site surveys. The many studies provide a broad base of knowledge for interpretation of the Challenger drill cores.

The IPOD Active Margins Panel focused its attention on testing the simple conceptual model of convergent margins in settings along continental and island arc margins. The Japan Trench area was considered an accretionary margin along an island arc composed of continental crust. Although it was recognized from the outset that drilling in the trench and the back-arc basin and penetrating the Benioff zone were beyond the capability of the Challenger, the upper part of the accretionary wedge was certainly within reach. The general plan of the panel was to characterize ocean basin materials seaward of the trench and terrigenous materials landward of the trench and then to try to distinguish between them in the accretionary wedge. This task was considered feasible off Japan because the trench was not filled with terrigenous sediment as are many other trenches. It was recognized that the lack of fill might be due to very rapid convergence; because the convergence rate derived from global considerations is about 8 $\mathrm{cm} / \mathrm{yr}$., terrigenous material might go unrecognized in seismic records. However, little terrigenous sediment was reported from DSDP sites drilled in the deep ocean basin nearby.

The IPOD plans became more specific with the availability of the results of the Japanese studies. Because few coherent reflecting horizons could be resolved in the first network of single-channel data taken by the Geological Survey of Japan (Honza et al., 1977), the trench inner slope was assumed to be structurally complex. A fairly persistent narrow midslope terrace separated the lower part of the trench inner slope from the upper slope covered by a blanket of what was thought to be terrigenous sediment. Beneath the terrigenous blanket not much structure was recorded. However, shortly after the single-channel studies were reported, two multichannel transects were released to IPOD by the Japan Petroleum Development Corporation (presently 
Japan National Oil Corporation, JNOC) (Nasu et al., this volume). These lines showed deeper structure and probably recorded most reflection horizons resolvable with high-powered seismic reflection techniques (demonstrated by the resolution of the Moho discontinuity under the trench and lower slope) (see seismic records, back pocket, this volume). These records were crossed and supplemented by an IPOD presite survey by the $\mathrm{Ha}$ kuho-maru of ORI. Single airgun, OBS, sonobuoy, and piston-coring investigations were made with emphasis on the proposed sites (Nasu and Kobayashi, 1980). The Japanese IPOD committee and panel members suggested a series of sites that were designed to (1) characterize the deep ocean basin sediment, (2) explore the accretionary wedge of the lower slope, (3) date the development of the midslope terrace, (4) measure at least a minimum rate of uplift of the shelf edge structure high, (5) test the seaward extent and age of continental crust, (6) indicate the age and geologic history of the deep sea terrace, and (7) examine diagenetic and structural changes of rocks subjected to stresses associated with plate convergence. Thus the main objectives of the Japan Trench transect were to learn more about the mechanism and dynamics of plate convergence and their effects on the sedimentation complex. The detailed objectives of individual sites are presented in the site reports.

\section{SUMMARY OF RESULTS}

IPOD geophysical data and drill sampling along the Japan Trench transect (Figure 1) indicate that material tectonically accreted during the present convergent episode is limited to a surprisingly small zone. The limits seem well established by the seaward extent of crust with continental thickness and lithologies and by the age and thickness of a terrigenous slope apron covering the presumed but probably unsampled accreted oceanic material.

The evidence for crust of continental affinities is anchored in part to the geologic history on land, and, as presently intepreted, the geologic history at Site 439 correlates in general with the history of Honshu Island. The Cretaceous unconformity, widely recognized on land, has now been observed $130 \mathrm{~km}$ east from the coast at Site 439. Because in seismic records and sampled sections the unconformity cuts across an ancient landmass, the former extent of the landmass is probably indicated by the extent of the unconformity in seismic records. In addition, because a volcanic arc like the one inferred to have been near Site 439 during the Oligocene is usually associated with a trench 100 to $200 \mathrm{~km}$ farther seaward, it is possible evidence that the landmass extended much farther east than Site 439. If this is true, a pre-Oligocene fore-arc area once extended hundreds of kilometers seaward of Site 439 (von Huene, Nasu, et al., 1978).

Ishiwada and Ogawa (1976) traced the unconformity from the Kitakami Massif on land, across the inner part of the continental margin. It can be continued seaward in the JNOC multichannel seismic records across Sites 438 and 439 , where it is clearly recorded under Site 435 , and farther seaward near the midslope terrace, where it is presently at a depth of $1 \mathrm{~km}$. Therefore it is likely that remnants of the Oyashio landmass, which was probably crust of continental thickness formed during a previous tec- tonic episode, extends at least to the seaward limit of the unconformity recorded by the seismic reflection surveys.

The exact seaward limit of the unconformity is unclear because it becomes difficult to follow in the region just upslope from the midslope terrace in the seismic record across Sites 434, 435, 440, and 441 . However, the overlying slope deposits extend farther seaward and merge into the accreted wedge. Therefore the sedimentary environments reflecting subsidence of the Oyashio landmass and deposition of terrigenous material on a deep sea terrace and trench slope extend to the midslope terrace at Site 440. Although there is little folding of this section in the multichannel records, rotational slumps do exist at Site 435 . The accreted wedge, characterized by highly diffracted reflections and a deeper series of dipping reflections, begins immediately seaward. Therefore the acoustically definable accreted wedge extends approximately $25 \mathrm{~km}$ landward of the trench axis to the vicinity of the midslope terrace. The base of the section beneath Site 440 , which is virtually in contact with the oldest part of the accreted wedge, is estimated to be no younger than early Miocene. Thus it is close in age to the initial volcanism of the late Oligocene which is associated with the present episode of convergence. At Sites 434 and 441 accretion can be no younger than the upper Miocene trench slope deposits.

We should probably not restrict the term "accreted" to materials scraped off the oceanic plate. Along the Japan Trench, a great deal of terrigenous material moving downslope never reaches the trench or oceanic plate before it is involved in compressional tectonic environment-for instance, the overcompacted sediments at Site 440 . Even at Sites 434 and 441 , closer to the trench, no definite material from the oceanic plate was recognized, yet a much greater amount of sediment accumulated here than at reference sections landward and seaward. Although some of this greater thickness may be due to local differences in rates of sedimentation, there is possible evidence in the repetition of diatom zones at Site 434 and downhole logs at Site 441 of tectonic stresses that may structurally thicken the section; therefore "accretion" in the dynamic sense of the term must include trench slope deposits.

Imbrication is the accretionary process most commonly associated with convergent margins, and some imbricate faulting has been interpreted from the seismic records (Langseth et al. 1978). In addition, downslope mass movement is indicated by hiatuses at the Pliocene/ Pleistocene boundary of sites on the trench slope, by evidence of intervals of transported material in cores, by syndepositional folding, and by scars and other evidence of slumping in the seismic records.

Our preliminary findings indicate that dewatering and development of pervasive fracturing are two important processes in the initial stage of tectonic consolidation of the mudstone encountered in cores from the Japan transect.

Preliminary calculations indicate that the zone of accretion associated with the Japan Trench is not large enough to accommodate all the sediment carried there in the Neogene by the subducted plate at the convergence rate of 8 to $10 \mathrm{~cm} / \mathrm{yr}$. proposed by Minster et al. 

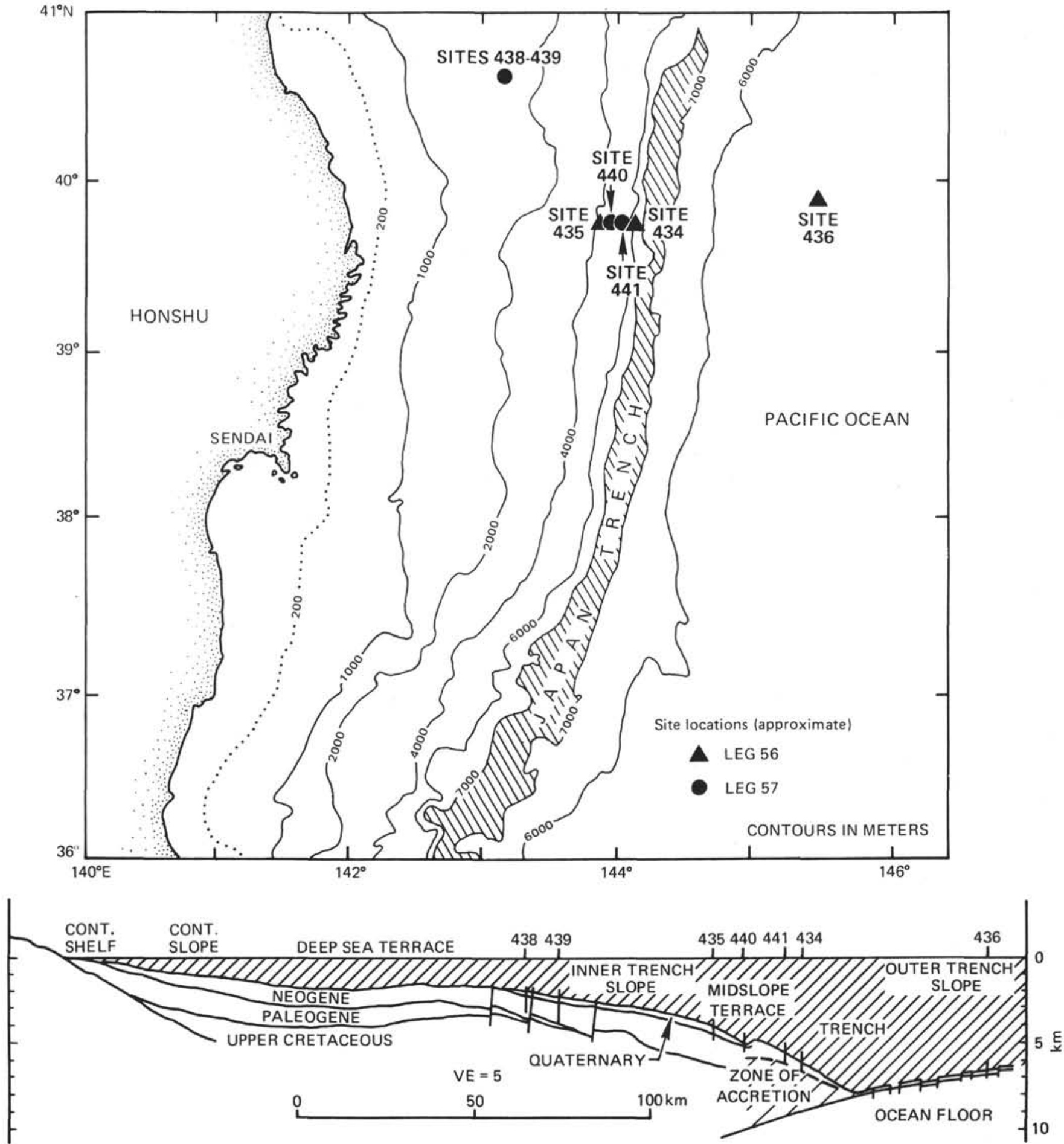

Figure 1. Index map of Japan fore-arc region showing location of drill sites for Legs 56 and 57 and a schematic cross section of the margin based on seismic records and drilling results.

(1974), despite a liberal allowance for compaction. Nor does a great deal of the stress across the slip plane between the upper and lower plates seem to be communicated landward of the midslope terrace, at least in the upper 2 to $3 \mathrm{~km}$ of the continental margin. Some of the puzzling problems raised by the preliminary study of the cores from Legs 56 and 57 and geophysical data across the sites are (1) the fate of the subducted and accreted oceanic (and continental) material, (2) the possible fate of the outer part of the Oyashio landmass, (3) the mechanism whereby massive subsidence of the leading edge of the continental plate can take place during presumed addition of oceanic crust to continental crust, and (4) the very low frictional forces that allow many thousands of kilometers of ocean crust to be thrust beneath the continental crust without deforming the upper plate ex- 
tensively. The results from this first transect in the IPOD Active Margins drilling program suggest that much more variability in structure may exist between convergent margins than has been recognized.

\section{Definitions}

Accreted wedge: Accreted wedge (Figure 2) (accretionary prism, accretionary wedge) is preferred here for the following reasons. Karig and Sharman (1975) use the term "'accretionary prism'" to denote the entire mass of the upper plate, from the seaward edge of the frontal arc to the trench axis. The genetic implications of this term as it is now used in the literature do not fit the Japan Trench area. We here use the term "accreted wedge" as the structural region from about the midslope terrace (off Japan) seaward to the trench axis, an area similar to that referred to as the "subduction complex" (Dickinson and Seely, 1979). The landward boundary of the accreted wedge along the Japan margin is marked by a structural discontinuity evidenced by a loss of coherent reflections in an organized sequence. In seismic reflection records the wedge appears as a region of highly disrupted, chaotic reflections above recognizable returns from the top of the igneous oceanic basement. The term "accreted wedge" is meant to have no genetic significance beyond signifying that the material within it has apparently been added or accreted to the seaward edge of a continental margin. The processes which operate to accrete this material are not specifically defined, nor is the source of the material itself (whether from the deep ocean basin or from terrigenous sources upslope). Although the term "'accreted wedge" is preferred, the terms "accretionary prism"' and "accretionary wedge", are used in several chapters according to the preference of the various authors.

Midslope terrace: marks seaward extent of continuous reflective sequence (q.v.), which is best delineated on the deep sea terrace and appears to extend at least under the upper part of the trench inner slope to this point.

Reflective sequence: consists of a regular subhorizontal stratified sequence which extends from 1 to 2 (1300-2500 m thick) on records; the sequence overlies an unconformity and locally laps onto this unconformity surface. In other areas it is conformable with that surface. The unconformity is marked by a diffractive horizon in seismic records which indicates surface roughness. Below this surface are obscured, steeply landward dipping reflections truncated by the unconformity surface. At Site 439 the age of the sedimentary complex underlying the reflective sequence is Cretaceous.

The other structural and morphologic features most commonly referred to in various chapters are shown in Figure 2.

\section{Biostratigraphic Zonations}

Legs 56 and 57 sites along the Japan Trench transect sampled a wide range of sediments, including carbonate-rich, highly fossiliferous sandy clays on the upper

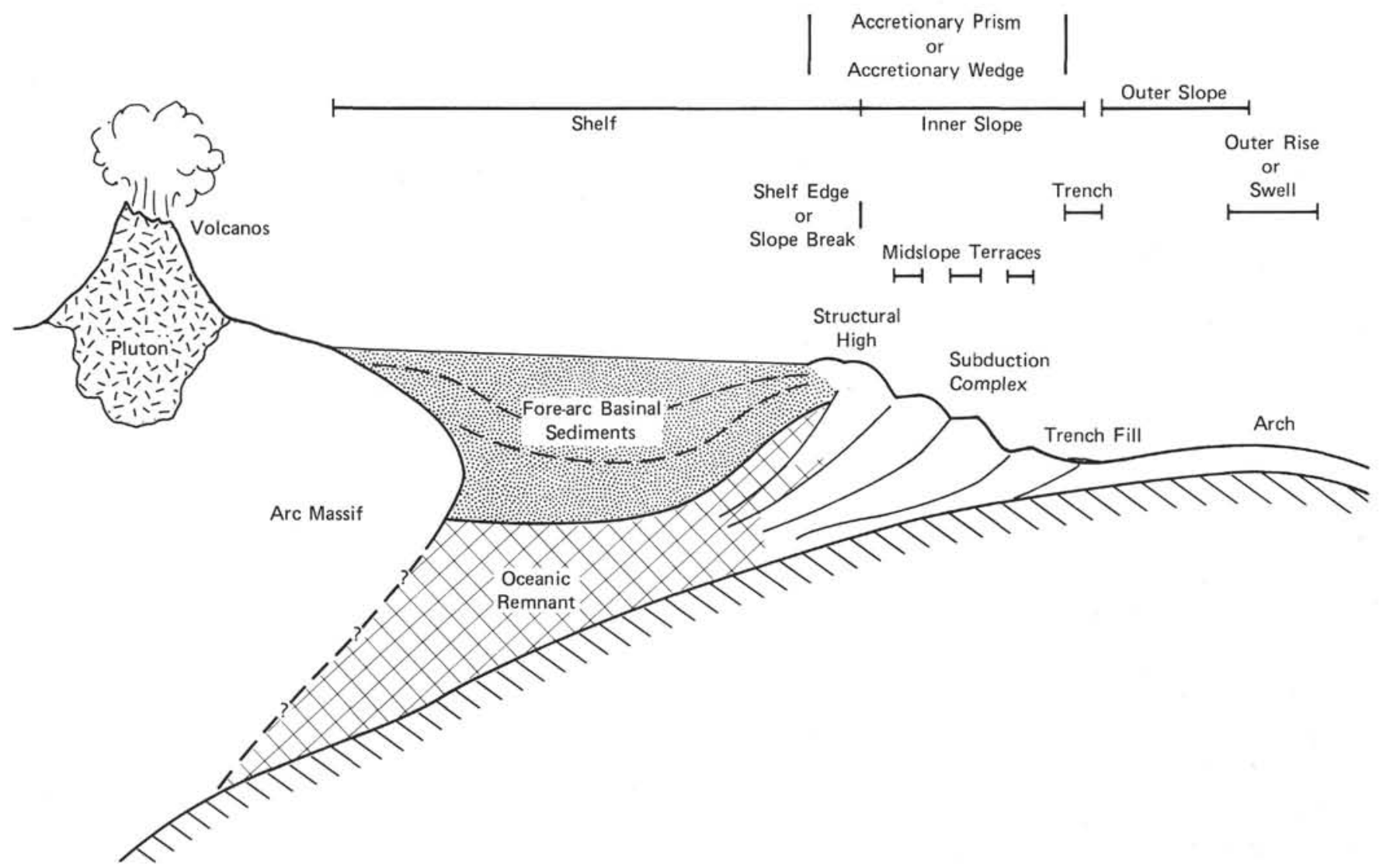

Figure 2. Terminology of the fore-arc regions (adapted from Dickinson and Seely, 1979). 
slope; muddy, fossil-poor diatom oozes near the bottom of the trench on the landward wall; and carbonate-free diatom oozes on the ocean plate. Preservation of microfossils varies with water depth and calcareous fossils were not recovered from deep-water sites. Planktonic foraminiferal preservation in surficial sediments in the Japan Trench area (Thompson, this volume) places the lysocline at about $\mathbf{2 0 0 0}$ meters. Microfossil abundances varied throughout the transect sites owing to dissolution, fluctuations in biogenic productivity in the late Tertiary, and downslope movements of sediment by slumping.

Pelagic microfossil biostratigraphies identified a complete late Tertiary sequence (only partially recovered in some sites), an upper Oligocene to lower Miocene sequence, an Upper Cretaceous black shale at the bottom of Site 439, and Lower Cretaceous radiolarian chert in Site 436. Dissolution and faunal changes due to climatic deterioration throughout the Tertiary created difficulties in applying any single biostratigraphic scheme for biostratigraphic subdivisions. Tropical and subtropical zonations could be used for the lower Tertiary, but midlatitude schemes were required for the Pliocene and Quaternary. In the late Pleistocene, variations in planktonic foraminiferal faunas indicated southward displacement of the Oyashio Current relative to its present-day location. As a result of these paleoclimatic and ecologic changes, the biostratigraphic zonal schemes used in the Japan Trench (Figure 3) transect are largely synthetic. The diatom zones (Barron, this volume; Harper, this volume) are modified after Koizumi (1975); radiolarian zones (Reynolds, this volume; Sakai, this volume) follow Foreman (1975) and Riedel and Sanfilippo (1977); nannofossil zonation is modified after Bukry (1975) for the Miocene and Pliocene and after Gartner (1977) for the Pleistocene. The planktonic foraminiferal zones of Blow (1969) have been included for convenience, but few of the index taxa are present in these mid-to-high latitude faunas. In the Leg 56 and 57 sites, temperate North Pacific datum levels have been correlated to Blow's zones (Thompson, this volume; Keller, this volume).

The geochronologic scale adopted here is that of LaBrecque et al. (1977), based on paleomagnetic determinations. Microfossil zonations have been keyed to the paleomagnetic stratigraphy in North Pacific piston cores and other DSDP sites. Paleomagnetic measurements in Site 438 are from Smetzer and Hall (this volume) and argon-argon dates from Yanagisawa et al. (this volume) and Moore and Fujioka (this volume); they permit a direct correlation of these sites to the paleomagnetic time scale.

\section{LITHOLOGIC CLASSIFICATION}

The basic classification system used here was devised by the JOIDES Panel on Sedimentary Petrology and Physical Properties (SPPP) and adopted for use by the JOIDES Planning Committee in March 1974. For the sake of continuity Legs 56 and 57 shipboard scientists have used this basic classification with some modifications. Since Legs 56 and 57 drilled in the same region and recovered sediment of similar lithology and age, the two legs have come to agreement on a uniform lithologic classification to facilitate comparison of sediment from different drill holes. We will point out differences from the SPPP classification at a later point.

\section{General Principles}

Because this classification is not comprehensive, a category of "Special Rock Types" will create additional definitions. The classification is descriptive, and genetic implications are not intended. The divisions are necessarily artificial and the proposed classification only a rough grouping of what we really find in nature. For the most part the classification in this volume is based on data estimated or measured aboard ship.

\section{Descriptive Data}

Sediment and rock names are defined on the basis of composition and texture. Composition is more important in describing deposits characteristic of open marine conditions; texture is more important for hemipelagic and nearshore facies. These data are primarily determined onboard the ship by visual estimates in smear slides with the aid of a microscope.

\section{Firmness}

We use three classes for biogenic calcareous rocks, which have a calcium carbonate content greater than 60 per cent, and only two classes of firmness for all other lithologic types. Criteria for different classes of firmness are those of Gealy et al. (1971).

1. Biogenic-calcareous sediment, with more than 60 per cent $\mathrm{CaCO}_{3}$, have three classes of firmness.

A. Soft: Sediment which has little strength and is readily deformed under the finer or broad blade of the spatula is soft and is termed ooze.

B . Firm: Partly lithified ooze or friable limestone is called chalk. Chalk is readily deformed under the fingernail or the edge of a spatula blade. More lithified chalks are termed limestones.

C. Hard: Limestone is a term restricted to nonfriable cemented rock.

2. Only two classes of firmness are used for transitional carbonates with less than 60 per cent $\mathrm{CaCO}_{3}$, biogenic siliceous sediment, pelagic clay, and terrigenous sediments.

A. Soft: A sediment is soft if the sediment core may be split with a wire cutter. The following sediment terms are used for soft sediment:

1) Soft biogenic-siliceous sediment (with more than 30 per cent siliceous fossils) is termed ooze; for example, radiolarian ooze, diatomaceous ooze, or siliceous ooze.

2) Soft terrigenous sediment, pelagic clay, and transitional calcareous-biogenic sediments are termed sand, silt, clay, mud, or marl.

B. Hard: The core is hard if it must be cut with a band saw or diamond saw.

1) Hard siliceous-biogenic sediment (more than 30 per cent siliceous) are termed radiolarite, diatomite, chert, or porcellanite. 


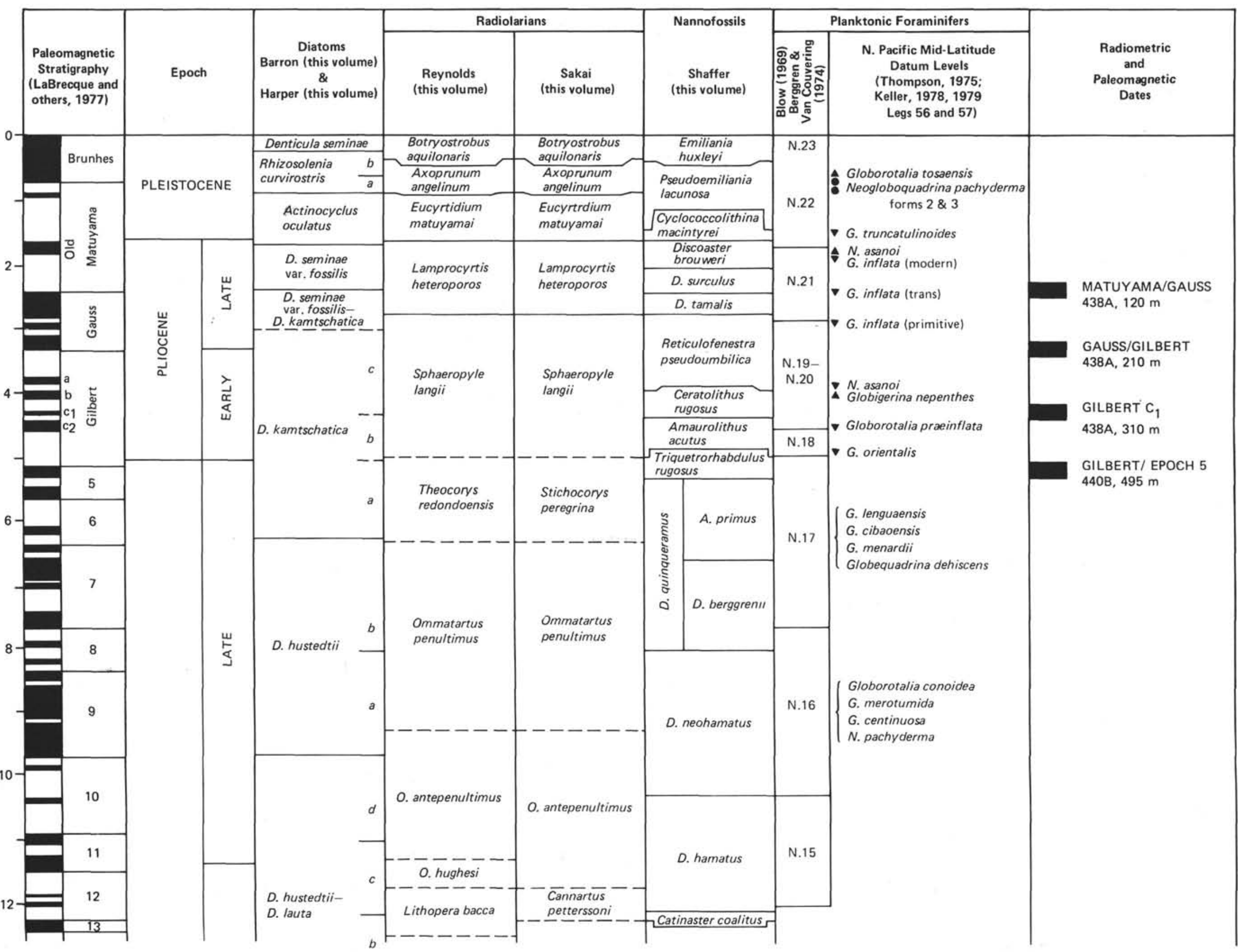




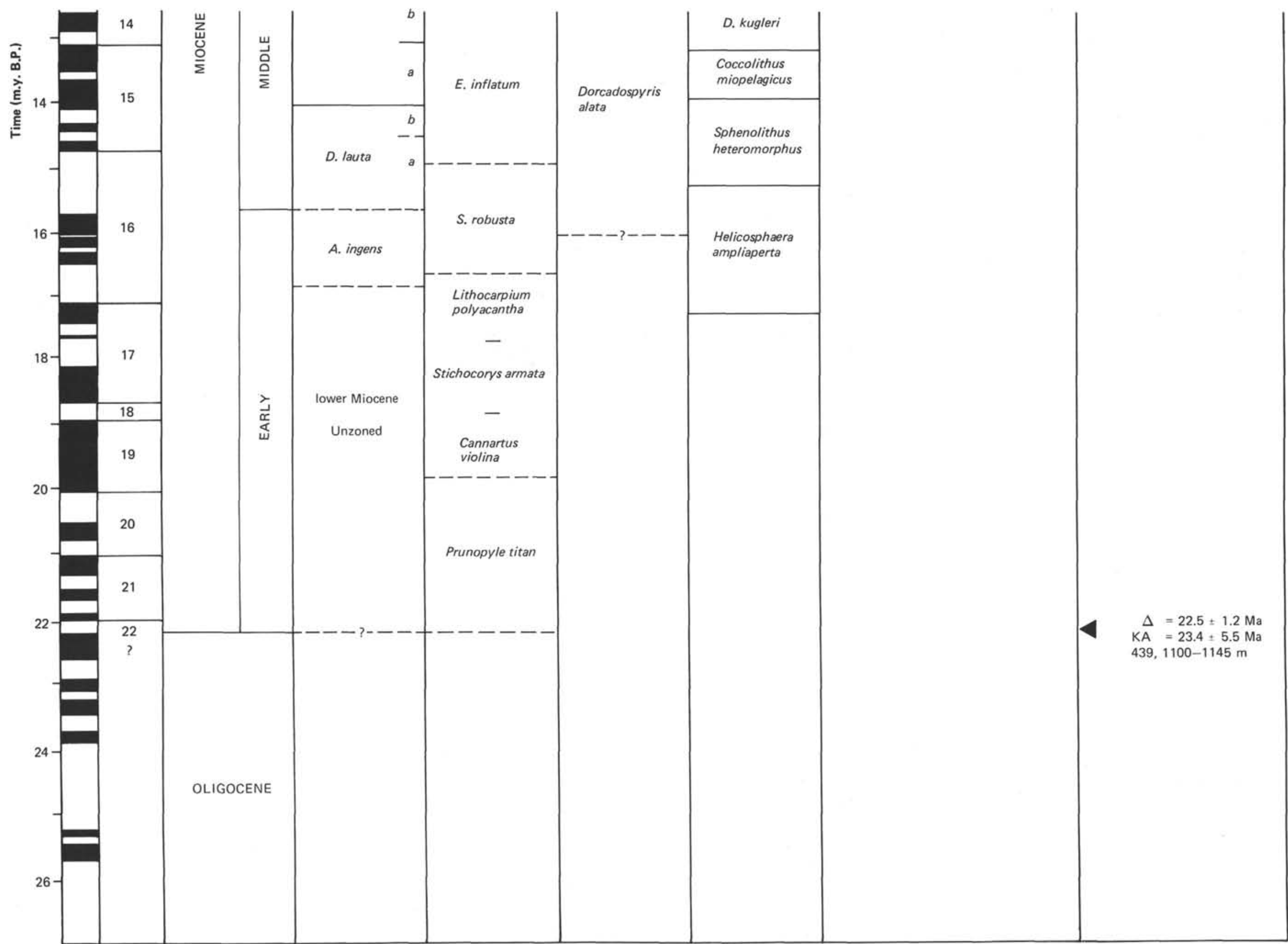


2) Hard terrigenous sediment, transitional calcareous-biogenic sediment, and pelagic clays are termed by adding the suffix "stone" to the soft sediment name - for example, sandstone, siltstone, claystone, mudstone (shale, if fissile), or marlstone.

\section{Basic Sediment Type}

\section{Pelagic Clay}

Pelagic clay is primarily authigenic pelagic deposits that accumulate at very slow rates. The class is often termed brown clay or red clay, but since these terms are confusing, they are not used.

1. Boundary of pelagic clay with terrigenous sediments is where authigenic components $(\mathrm{Fe} / \mathrm{Mn}$ micronodules, zeolites), fish, debris, etc., become common ( $>10$ per cent) in smear slides. Because the accumulation rates of pelagic clay and terrigenous sediments are very different, transitional deposits are exceptional.

2. Boundary of pelagic clay with siliceous-biogenic sediments is where there is less than 30 per cent siliceous remains.

3. Boundary of pelagic clay with calcareous-biogenic sediment is uncommon. Generally this facies passes from pelagic clay through siliceous ooze to calcareous ooze, with one important exception: at the base of many oceanic sections, black, brown, or red clays occur directly on basalt, overlain by or grading up into calcareous sediments. Most of the basalt clayey sediments are rich in iron, manganese, and other metallic trace elements. For proper identification they require more elaborate geochemical work than is available onboard ship. These sediments are placed in the Special Rock Category.

\section{Pelagic-Siliceous-Biogenic Sediment}

Pelagic-siliceous-biogenic sediment is distinguished from pelagic clay by containing more than 30 per cent siliceous microfossils. Siliceous-biogenic sediments are distinguished from a calcareous category by a calcium carbonate content of less than 30 per cent.

For a pelagic-biogenic-siliceous sediment with 30 to 100 per cent siliceous fossils, the following terminology is used:

1. Soft: Siliceous ooze (radiolarian ooze, diatomaceous ooze, etc., depending on the dominant fossil component).

2. Hard: Radiolarite, diatomite, chert, or porcellanite. The term "chert" in the past has been used in a very broad sense to designate almost any form of recrystallized silica. The term "porcellanite" (which also had a very broad usage in the past) will be used here to refer to "low density, more or less porous and dull-lustered varieties of 'chert' made of opaline silica or cristobalite. . ." (Lancelot, 1971). In the present volume chert will refer only to "hard nodules and sometimes beds, that are largely quartz and/or chalcedony, and show a conchoidal fracture and a vitrous luster . . ." (Lancelot, 1971).
3. Compositional qualifiers. If diatoms and radiolarians are the principle components, one or two qualifiers are used - for example: Indeterminate siliceous fossils: Siliceous ooze, chert or porcellanite

Radiolarians only: Radiolarian ooze or radiolarite Diatoms only: Diatomaceous ooze or diatomite Diatom < radiolarians: Diatomaceous radiolarian ooze or diatomaceous radiolarite

Diatom > radiolarians: Radiolarian diatomaceous ooze or radiolarian diatomite

The order of the two modifiers in the terms is dependent on the dominant fossil type. The most dominant component is listed last and the minor component first.

Terminology for the pelagic clay transition with diatom sediments is as follows:

\begin{tabular}{ccl}
$\begin{array}{l}\text { Biogenic- } \\
\text { Siliceous } \\
\text { Fossil Par- } \\
\text { ticles } \\
(\%)\end{array}$ & $\begin{array}{l}\text { Clay } \\
(\%)\end{array}$ & \multicolumn{1}{c}{ Lithologic Type } \\
\hline$<10$ & $>90$ & $\begin{array}{l}\text { Clay (soft) } \\
\text { Claystone (hard) }\end{array}$ \\
$30-10$ & 70 to 90 & $\begin{array}{l}\text { diatomaceous mud (soft) } \\
\text { diatomaceous mudstone } \\
\text { (hard) }\end{array}$ \\
$60-30$ & 40 to 70 & $\begin{array}{l}\text { muddy diatomaceous ooze } \\
\text { (soft) } \\
\text { muddy diatomite (hard) }\end{array}$ \\
$100-60$ & 0 to 40 & $\begin{array}{l}\text { diatomaceous ooze (soft) } \\
\text { diatomite (hard) }\end{array}$ \\
\hline
\end{tabular}

Other terms may be substituted for "diatomaceous" and "diatomite," respectively, as follows: (1) radiolarian and radiolarite if radiolarians are predominant or (2) siliceous chert if the fossil type is indeterminant.

We have divided the component frequencies into four major groups: $<30$ per cent, 10 to 30 per cent, 30 to 60 per cent, and $>60$ percent. These boundaries have been used for both calcareous and siliceous components and thus depart slightly from the SPPP classification, which employs only one major subdivision ( 50 per cent) in the biogenic siliceous sediments: $<50$ per cent siliceous fossils $=$ siliceous mud and $>50$ per cent siliceous fossils $=$ siliceous ooze. To be consistent we choose to subdivide both siliceous and calcareous pelagic facies in the same way.

\section{Pelagic-Biogenic-Calcareous Sediment}

Pelagic-calcareous sediment is distinguished by having a biogenic $\mathrm{CaCO}_{3}$ content in excess of 30 per cent. There are two classes: (1) pelagic-biogenic-calcareous sediments, which contain 60 to 100 per cent biogenic $\mathrm{CaCO}_{3}$, and (2) transitional-biogenic-calcareous sediments, which contain 30 to 60 per cent $\mathrm{CaCO}_{3}$. 
1. For the pelagic-biogenic-calcareous sediment with 60 to 100 per cent $\mathrm{CaCO}_{3}$, the following terminology is used:

A. Soft: Calcareous ooze

B. Firm: Chalk

C. Hard and cemented: Limestone

D. Compositional qualifier: If nannofossils and foraminifers are the principal components, one or two qualifiers are used - for example: Indeterminate carbonate fossils: Calcareous ooze, calcareous chalk, or calcareous limestone; Foraminifers ( 0 - 10 per cent)-nannofossils (90-100 per cent): Nannofossil ooze, nannofossil chalk, or nannofossil limestone; Foraminifers (10-25 per cent)-nannofossils (75-90 per cent): Foraminiferal-nannofossil ooze, foraminiferal-nannofossil chalk, or foraminiferal-nannofossil limestone; Foraminifers (2550 per cent)-nannofossils (50-75 per cent): Nannofossil-foraminiferal ooze, nannofossilforaminiferal chalk, or nannofossil-foraminiferal limestone.

2. The transitional-biogenic-calcareous sediments with 30 to 60 per cent $\mathrm{CaCO}_{3}$ are termed marl or marlstone as follows:

A. Soft: Calcareous marl, foraminiferal marl, or nannofossil marl

B. Hard: Calcareous marlstone, foraminiferal marlstone, or nannofossil marlstone

Note that the use of the terms "marl" or "marlstone" differs from the SPPP panel classification. The panel classification used "marly" as an adjective to ooze, chalk, or limestone (e.g., marly limestone) to denote sediments which had 30 to 60 per cent biogenic carbonate.

Terminology for the pelagic clay transition with the nannofossil sediments is as follows:

\begin{tabular}{ccl}
$\begin{array}{c}\text { Biogenic- } \\
\text { Calcareous } \\
\begin{array}{c}\text { Particles } \\
(\%)\end{array}\end{array}$ & $\begin{array}{c}\text { Clay } \\
(\%)\end{array}$ & \multicolumn{1}{c}{ Lithologic Type } \\
\hline $0-10$ & $90-100$ & $\begin{array}{l}\text { clay (soft) } \\
\text { claystone (hard) }\end{array}$ \\
$30-10$ & $70-90$ & $\begin{array}{l}\text { nannofossil mud (soft) } \\
\text { nannofossil mudstone (hard) }\end{array}$ \\
$60-30$ & $40-70$ & $\begin{array}{l}\text { nannofossil marl (soft) } \\
\text { nannofossil marlstone (hard) }\end{array}$ \\
$100-60$ & $0-10$ & $\begin{array}{l}\text { nannofossil ooze (soft) } \\
\text { nannofossil chalk (firm) } \\
\text { nannofossil limestone (hard) }\end{array}$ \\
\hline
\end{tabular}

Other terms may be substituted for "'nannofossil," such as (1) foraminiferal, nannofossil-foraminiferal, foraminiferal-nannofossil, if foraminifers are present in the percentages as discussed, and (2) calcareous, if the fossil types are indeterminate.

\section{Terrigenous Sediments}

Terrigenous sediments are distinguished by a terrigenous component in excess of 30 per cent and siliceous and authigenic components, each less than 10 per cent.

Sediments in this category are subdivided into textural groups (by smear slide estimation or grain-size analysis on the basis of the relative proportions of sand, silt, and clay. The size limits are those defined by Wentworth (1922). Textural classification follows the triangular diagram of Shepard (1954) (Figure 4).

The transition between pelagic and terrigenous sediments is termed hemipelagic. This is the dominant type of sediment encountered during continental margin drilling. As such it is treated separately.

\section{Hemipelagic Sediments}

Hemipelagic sediments are distinguished by a terrigenous component in excess of 30 per cent, a total nonbiogenic component in excess of 40 per cent, and a biogenic silica content in excess of 10 per cent. Besides the terrigenous component, hemipelagic sediments are usually rich in biogenic silica (usually diatoms, because of coastal upwelling) and volcanic ash (predominantly along active margins). The classification of these sediments in terms of the dominant components can be represented by a pyramid in which the peak and each corner represent 100 per cent of a specific component: 100 per cent sand at the peak; 100 per cent silt and 100 per cent clay at diagonal corners of the base; and 100 per cent biogenic silica and 100 per cent ash at the other diagonal corners of the base. As such, Shepard's textural classification (1954; Figure 3) would be represented by the plane passing through the points for 100 per cent sand, 100 per cent silt, and 100 per cent clay.

The plane of the base of the pyramid (Figure 4) shows the classification of sediments with less than 10 per cent sand component. Such sediments are the dominant type found on most continental margins, and thus the classi-

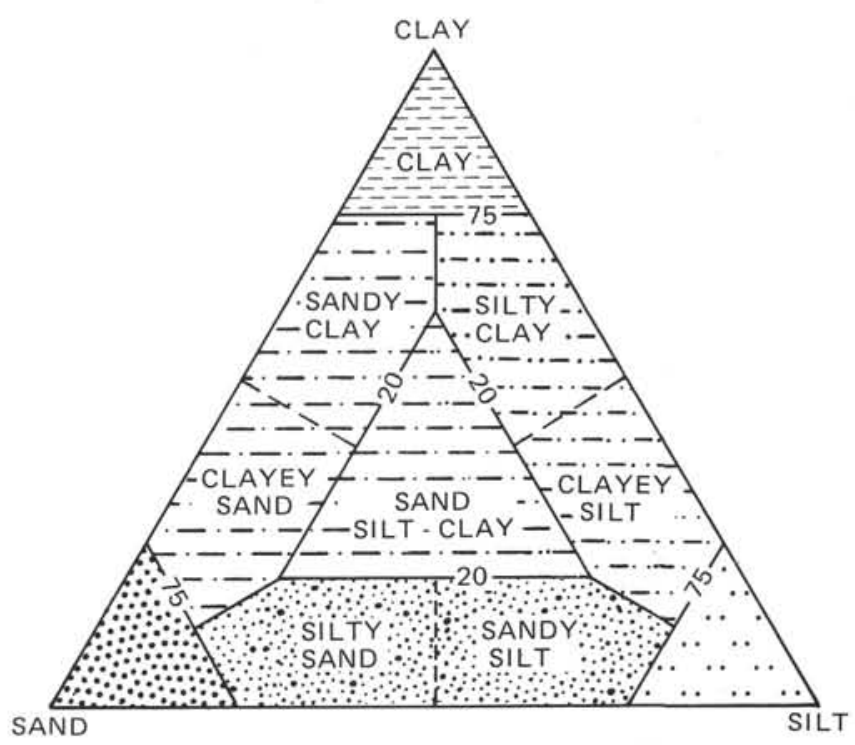

Figure 4. Textural classification of clastic sediments (after Shepard, 1954). 
fication in Figure 5 is broadly applicable. The percentage silt and clay used in the diagram (Figure 5) refers only to terrigenous components. Authigenic minerals, ash, and biogenic particles are not included.

For biogenic opal content greater than 10 per cent, the dominant siliceous biogenic component should be used in the name. Since diatoms predominate in these sediments, we have used the terms "diatomaceous" and "diatomite" in the diagram. However, if other biogenic siliceous components dominate, the terms "radiolarian," "radiolarite," "spicular," etc., may be used.

Components such as sand, diatoms, radiolarians, spicules, ash, etc., may be used as qualifiers to the original sediment description if their abundance is 10 to 30 per cent of the sediment - for example: Clayey vitric diatomaceous ooze, Diatomaceous sandy silty claystone, Diatomaceous vitric silty clay. The textural part of the classification should always be grouped. For example, one should not use: Vitric clayey diatomaceous ooze, Sandy diatomaceous silty claystone. Within the textural group and the component the modifiers are listed in order of increasing sedimentary abundance.

\section{Volcanogenic Sediments}

Pyroclastic rocks are described according to the textural and compositional scheme of Wentworth and Williams (1932). There are three textural groups: $>32 \mathrm{~mm}$, volcanic breccia; $32 \mathrm{~mm}$ to $4 \mathrm{~mm}$, volcanic lapilli; $<4$ $\mathrm{mm}$, volcanic ash (tuff when indurated). The composition of these pyroclastic rocks are described as vitric (glass), crystalline, or lithic.

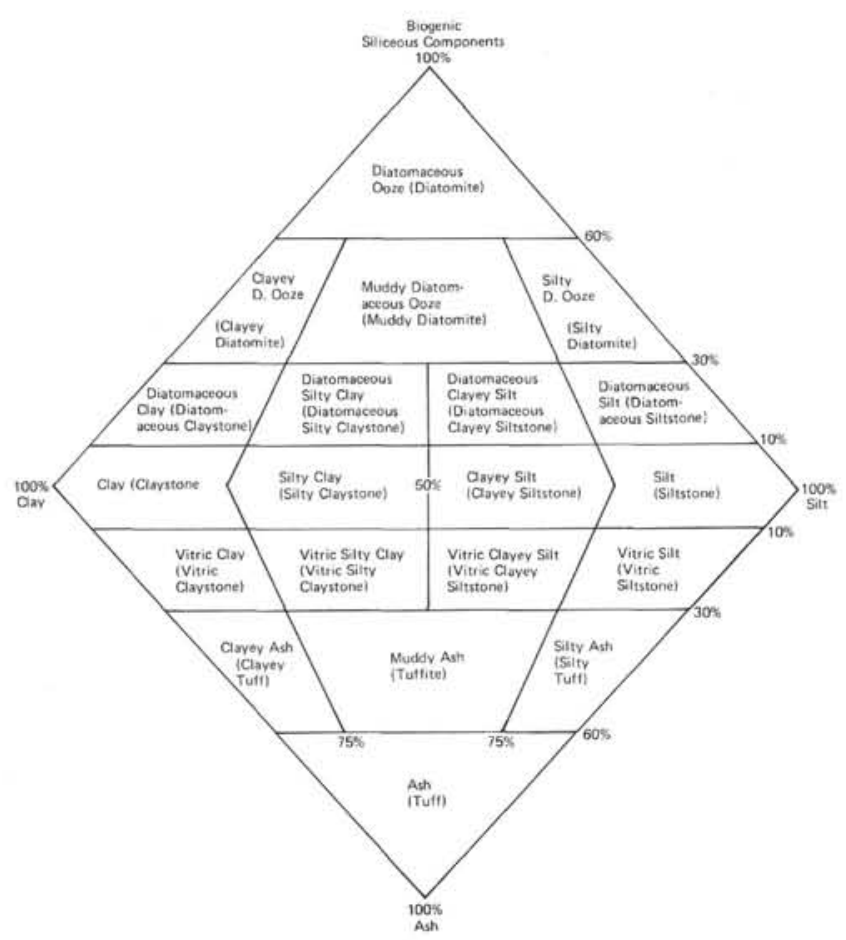

Figure 5. Hemipelagic sediment classification for use on Legs 57 and 57.
Sediments rich in ash are described in the following manner:

\begin{tabular}{cll}
\hline Ash(\%) & Soft-Sediment & Indurated \\
\hline $0-10$ & Mud & Mudstone \\
$10-30$ & Vitric mud & Vitric mudstone \\
$30-60$ & Muddy ash & Tuffite \\
$>60$ & Ash & Tuff \\
\hline
\end{tabular}

\section{QUALIFIERS}

In general sediments containing various constituents in the 10 to 30 per cent range may be identified in the name of sediments such as vitric diatomaceous mud or vitric muddy diatomaceous ooze. If more than one such qualifier is used, they are listed in order of increasing abundance in the sediment.

\section{PHYSICAL PROPERTIES-PROCEDURES}

A thorough discussion of physical properties is presented by Boyce (1976) with respect to equipment, methods, errors, correction factors, and problems related to coring disturbance. Only a brief review of methods employed on Legs 56 and 57 is given here.

\section{Velocity}

Compressional wave velocity was measured on the Hamilton Frame Velocimeter by timing a $400-\mathrm{kHz}$ pulse between two transducers and by measuring the distance across the sample with a dial gauge. Measurements were made at laboratory temperature and pressure, ideally about four hours after obtaining a core, but frequently within two hours. In general, core temperatures were found to be 3 to $4^{\circ} \mathrm{C}$ lower than room temperature, even after sitting uncut overnight. Soft unconsolidated sediments were generally measured on the split core; correction factors established by Boyce (1976) were used to compensate for increased thickness and travel time due to the liner $(0.256 \mathrm{~cm}$ and $1.180 / \mu \mathrm{s}$, respectively). With consolidated sediments, a piece was removed from the core and trimmed carefully to form two parallel surfaces to ensure good contact with the transducer heads. Water, glycerine, and Dow-11 silicone lubrication compound were used to make good acoustical contact between the sample and the transducers; glycerine and Dow-11 were primarily used with porous or friable samples whose physical properties would have been adversely affected by water.

Calibration of the velocimeter consisted of making numerous measurements through lucite, aluminum, and brass standards of varying thicknesses to obtain a calibration constant for each of three $\mu \mathrm{s}$ per $\mathrm{cm}$ settings on the DSDP Tektronix 485 oscilloscope used to make the travel time measurements. This calibration constant reflects the position picked by the operator as representing the first break from horizontal of the sonic signal. Data from the calibrations are summarized in Table 1. 
TABLE 1

Calibration Factors for DSDP Tektronix 485 Oscilloscope, Legs 56 and 57. A. Calibration Constants for Leg 56.

B. Calibration Constants for Leg 57

A

\begin{tabular}{|c|c|c|c|c|c|c|}
\hline$\mu \mathrm{s} / \mathrm{cm}$ setting & 1 & \multicolumn{3}{|c|}{2} & \multicolumn{2}{|c|}{5} \\
\hline $\begin{array}{l}\text { Thickness of } \\
\text { semistandards }\end{array}$ & 2.54 & \multicolumn{2}{|c|}{2.54} & 5.0 & 2.54 & 5.0 \\
\hline Lucite $\left(K^{\prime}\right)$ & - & \multicolumn{2}{|c|}{1.002} & - & 0.995 & 0.998 \\
\hline Brass $\left(K^{\prime}\right)$ & 1.008 & & 07 & 1.012 & 1.006 & 1.010 \\
\hline Aluminum $\left(K^{\prime}\right)$ & \multirow{2}{*}{$\begin{array}{l}1.010 \\
1.009\end{array}$} & & 16 & 1.008 & 1.017 & 0.999 \\
\hline Average $K$ & & \multicolumn{3}{|c|}{1.009} & \multicolumn{2}{|c|}{1.004} \\
\hline \multicolumn{7}{|c|}{ B } \\
\hline$\mu \mathrm{s} / \mathrm{cm}$ setting & \multicolumn{3}{|c|}{2} & \multicolumn{3}{|c|}{5} \\
\hline $\begin{array}{l}\text { Thickness of } \\
\text { standards }(\mathrm{cm})\end{array}$ & 2.54 & 5.08 & 7.16 & 2.54 & 5.08 & 7.16 \\
\hline Lucite $\left(K^{\prime}\right)$ & 1.011 & - & - & 1.004 & 1.001 & 0.999 \\
\hline Brass $\left(K^{\prime}\right)$ & 1.003 & 1.013 & - & 0.983 & 1.007 & 1.044 \\
\hline Aluminum $\left(K^{\prime}\right)$ & 0.993 & 0.998 & 1.004 & 0.999 & 0.995 & 0.999 \\
\hline Average $K$ & & 1.004 & & & 1.003 & \\
\hline
\end{tabular}

Note: $K^{\prime}$ is a correction factor for a block of material of known velocity (V) such that $\mathrm{V}_{\text {measured }} \times K^{\prime}=\mathrm{V}_{\text {true }} \cdot K^{\prime}$ is determined for various thickness of different standards at a particular $\mu \mathrm{s} / \mathrm{cm}$ setting on the oscilloscope. The average correction factor, $K$, is then determined for each $\mu \mathrm{s} / \mathrm{cm}$ setting. This correction factor is applied to the velocity of the cored section measured onboard ship. For a detailed discussion, see Boyce (1976).

\section{GRAPE}

The Gamma Ray Attenuation and Porosity Evaluator (GRAPE) was used to determine wet bulk density based on the attenuation of gamma rays by the sample. Boyce (1976) discusses the theoretical aspects in detail. During Legs 56 and 57 the GRAPE was used in two modes: (1) continuous GRAPE, in which most sections of the core were irradiated; continuous "corrected" wet bulk density (relative to quartz) was plotted on an analog graph; and (2) two-minute GRAPE, in which the gamma count through a small piece of the core was measured for two minutes, followed by a similar count through air and/or a quartz standard.

\section{Continuous GRAPE}

Prior to running each core through the device, an aluminum standard was measured. A density of $2.60 \mathrm{Mg} / \mathrm{m}^{3}$ was assigned to the $6.61-\mathrm{cm}$ (diameter) aluminum standard analog record and a density of $1.0 \mathrm{Mg} / \mathrm{m}^{3}$ to the 2.54-cm (diameter) aluminum standard analog record. Linear interpolation of the GRAPE analog data between these values yielded an "empirical" wet bulk density of the sediment sample in the core $\left(p_{b c z}\right)$. If the sample completely filled the core, then $p_{b c}=p_{b c z}$, where $p_{b c}$ $=$ "corrected" wet bulk density (relative to quartz). Then:

$$
p_{b}=\frac{\left(p_{b c}-p_{f c}\right)\left(p_{g}-p_{f}\right)}{\left(p_{g c}-p_{f c}\right)}+p_{f},
$$

where $p_{g}=$ true grain density $\left(\simeq 2.7 \mathrm{Mg} / \mathrm{m}^{3}\right.$ for sediments, although actual grain densities were deter- mined subsequently to range from 2.41 to $2.43 \mathrm{Mg} / \mathrm{m}^{3}$ ); $p_{g c}=$ corrected grain density $\left(\simeq 2.7 \mathrm{Mg} / \mathrm{m}^{3}\right.$ for sediment $) ; p_{f}=$ true fluid density $\left(\simeq 1.025 \mathrm{Mg} / \mathrm{m}^{3}\right) ; p_{f c}=$ corrected fluid density $\left(\simeq 1.128 \mathrm{Mg} / \mathrm{m}^{3}\right)$; and $p_{b}=$ true wet bulk density.

Using the above values,

$$
p_{b}=1.066\left(p_{b c}-1.128\right)+1.025 .
$$

If the sample did not fill the core, then corrections were made, depending on the diameter of the rock core and on the nature of the materials surrounding the core (air, water, sediment, or breccias). Then:

$$
p_{b c}=\frac{100 p_{b c z}-S X}{100-X},
$$

where $S=$ "corrected" wet bulk density of the material around the core and

$$
X=100 \frac{6.61-\text { (gamma ray path length, in } \mathrm{cm})}{6.61} \text {. }
$$

Values for $S$ were:

$$
\begin{aligned}
& S=0.0 \mathrm{Mg} / \mathrm{m}^{3} \text { for air } \\
& S=1.1 \mathrm{Mg} / \mathrm{m}^{3} \text { for water } \\
& S=1.4 \mathrm{Mg} / \mathrm{m}^{3} \text { for sediment slurry } \\
& S=1.8 \mathrm{Mg} / \mathrm{m}^{3} \text { for drilling breccia }
\end{aligned}
$$

For lack of any method of determining whether or not an undersized core was aligned with the beam, the gamma ray path length was assumed to equal the core diameter.

The $p_{b c}$ determined by equation (2) is used in equation (1) to calculate $P_{b}$. Shipboard reduction of analog GRAPE records involved (1) selection of high density portions of each core section on the analog record, (2) determination from core photographs of core diameter and composition of material around the core, and (3) calculation of true wet bulk density $\left(p_{b}\right)$ by formulas (1), (2), and (3). These calculations were subsequently corrected for independently determined true grain densities. The $p_{b c}$ determined by equation (2) is used in equation (1) to calculate $p_{b}$. The porosity $\phi$ is obtained by

$$
\phi(\%)=\frac{p_{g}-p_{b}}{p_{g}-p_{f}} \times 100 .
$$

\section{Two-Minute GRAPE}

For two-minute GRAPE calculations,

$$
p_{b c}=\frac{\ln \left(I_{o} / I\right)}{d \mu q t z}
$$

where $I_{o}=$ two-minute gamma count through air, $I=$ two-minute gamma count through the sample, $d=$ gamma ray path length through the sample, and $\mu q t z=$ quartz attenuation ceofficient determined daily by measuring through a quartz standard. Then, as in the continuous GRAPE calculation (assuming a 2.7 grain density), 


$$
p_{b}=1.066\left(p_{b c}-1.128\right)+1.025
$$

and

$$
\phi(\%)=\frac{100\left(2.70-p_{b}\right)}{1.675}
$$

Boyce (1976) estimates \pm 5 per cent accuracy for continuous GRAPE data and \pm 2 per cent for two-minute GRAPE data. In practice, it was found that the error on Legs 56 and 57 seemed to be higher, owing in part to the highly disturbed nature of many of the cores and in part to errors in gamma ray travel path determinations due to the extremely friable nature of the sediments. However, good agreement exists between the GRAPE data from selected portions (as just described) of nearly every section and the gravimetric methods (syringe and rock chunk).

\section{Gravimetric Technique: Syringe and Rock Chunk}

In a soft sediment (recovered to depth $\$ 50 \mathrm{~m}$ ), a $1-\mathrm{cm}^{3}$ syringe was used to collect a measured volume of material for onboard analysis. In harder sediments (and in the majority of all cores), a $20-$ to $50-\mathrm{cm}^{3}$ chunk of material was collected. A small piece of this chunk was used for water content determination only; the remainder was used for a volume determination by immersion in water; wet bulk density, porosity, and water content were then determined. No salt corrections were applied in any of these techniques. Drying and weighing facilities were present onboard for carrying out these measurements.

Water content (per cent net weight $)=100 \times[$ (weight wet sediment) - (weight dry sediment) $] \div$ (weight wet sediment).

$$
\text { Wet bulk density } \mathrm{Mg} / \mathrm{m}^{3}=\frac{\text { weight of wet sediment }}{\text { volume of wet sediment }} \text {. }
$$

The $1-\mathrm{cm}^{3}$ syringe samples provided a volume measurement. However, Bennett and Keller (1973) note that the volume is actually too small for accurate determinations. The method is also highly dependent on sampling techniques; any cracks or voids in the sample lead to large inaccuracies. In addition, despite all precautions, some compression of the sample was noted in almost all samples taken during the cruise, thus leading to inaccuracies in the volume measurement. Large samples taken for shore-based determinations are much more accurate.

The syringe and rock chunk methods also give porosity as follows:

$$
\text { Porosity }(\%)-100 \times \frac{\text { weight of evaporated water }}{\text { volume of wet sediment }}
$$

In general, the gravimetric techniques give useful data for comparison with the GRAPE data, and when good sampling techniques are followed (and good samples are available) the data generally compare well.

\section{Vane Shear}

A CL-600 Torvane and a Wykeham-Farrance laboratory vane shear apparatus were used onboard to determine the undrained shear strength of clayey sediments. The Torvane was hand-rotated at a rate designed to reach failure in about $10 \mathrm{~s}$ with constant loading. All measurements for each leg were made by the same person. Repeated determinations yielded results which were generally reproducible to \pm 15 per cent. Measurements were made in the least disturbed sections of the core on horizontal surfaces. Measurements were discontinued when cracking of the sediments was observed, indicating failure by fracturing rather than by shear. Lee (1973) finds that estimated in situ strengths are higher than laboratory measurements by a factor of 2 or 3 .

The Wykeham-Farrance vane shear apparatus was used at Sites 438 and 440 on Leg 57. Measurements were made only on undisturbed sections of the split core at an orientation parallel to bedding. A $1.28-\mathrm{cm}$ vane was inserted $1 \mathrm{~cm}$ into the (half) core and was rotated by a motor at $89^{\circ} /$ minute. Resistance springs were selected so that shearing occurred between $30^{\circ}$ and $110^{\circ}$ stress. Shear strength was calculated by (Boyce, 1975):

$$
\tau_{f}=c=\left[\frac{2 t}{\pi d^{2} h\left(1+\frac{2}{3 n}\right)}\right] \begin{aligned}
& \text { (maximum degree } \\
& \text { spring stress), }
\end{aligned}
$$

where $\tau_{f}=c=$ cohesion and shear strength of clay at failure, $t=$ spring torque factor in $\mathrm{gcm} /$ degree, $d=\mathrm{di}$ ameter of vane blades, and $h=$ height of vane blades. Subsequent to failure, the vane was rotated through two complete revolutions within the sediment, the sediment was allowed to set for $10 \mathrm{~min}$., and the test was repeated to determine the remolded shear strength.

\section{Thermal Conductivity Measurements}

Two instruments were available for thermal conductivity measurements: (1) a standard heated line source needle probe device loaned to the Challenger by the University of Tokyo, courtesy of Professor S. Uyeda of the Earthquake Research Institute; and (2) a Quick Thermal Meter (QTM) loaned to the Challenger by Showa Denko for a trial period. Most of the measurements reported were made using the QTM, since this device provides a very fast and simple measurement. The needle probe instrument was available on Leg 56 and was used primarily as a basis for comparison of the QTM results.

\section{The Quick Thermal Meter}

The Quick Thermal Meter (QTM) is a new type of apparatus for quickly determining the thermal conductivity of materials in the range of 0.023 to $11.7 \mathrm{Wm}^{-1} \mathrm{~K}^{-1}$. The method is an extension of the widely used needle probe technique, with the difference that the heater and temperature sensor are mounted on a flat surface with known conductivity. The material being measured must have a relatively flat and smooth surface at least the size 
of the flat surface on the probe. In operation, the flat surface of the probe is lightly spring-loaded against the surface to be measured, and a constant power is applied to the heater. Temperature rise is monitored by a thermocouple, and the rate of rise of temperature can be interpreted in terms of the thermal conductivity of the surface. The observation period can be selected as 20,30 , or $40 \mathrm{~s}$. In all cases, the first temperature point is taken at $10 \mathrm{~s}$ and the second at the end of the observation period. An internal calculator in the QTM calculates the conductivity, based on the two temperature points, and displays the results digitally on a panel. The QTM system provides three standard materials that are used to test the calibration of the instrument and reproducibility of measurements.

On Legs 56 and 57, the QTM was used on split sediment cores to measure conductivity. Most of the cores were firm enough so that the probe could be placed on a flat split core face. With very firm sediment, the splitting of a core produced a rough and crumbly surface that had to be leveled and smoothed before applying the QTM probe; otherwise the boundary resistance was so high that invalid, very low readings were obtained. When the core material was hard enough to require sawing, the sawed surface had to be cleaned and scraped smooth.

Generally, cores in sealed liners were allowed to rest for two hours or more in the core lab before splitting. After some experimentation, it was found that the QTM should be left on the sample surface for $30 \mathrm{~s}$ or more to equilibrate thermally with the core material before initiating a measurement. The core materials were always saturated with water, and evaporation of water at the surface was the major source of transients. Leaving the probe in place for $30 \mathrm{~s}$ suppressed evaporation and allowed time for the disturbance to dissipate. A premeasurement waiting period of less than $30 \mathrm{~s}$ introduced serious errors into the thermal conductivity observations. After Core 10 of Site 435, the 40-s observation period was always used, under the assumption that this waiting period would minimize near surface effects by sensing a larger volume.

\section{Needle Probe Measurements}

In the needle probe apparatus, the heater and temperature sensor are contained in a very fine needle, approximately $1 \mathrm{~mm}$ in diameter and $6 \mathrm{~cm}$ long. The needle can be inserted directly into soft sediment. In such sediments the needle was usually inserted into the end of the core half parallel to the axis of the core. A wait of about $30 \mathrm{~min}$. for equilibration preceded the 4-min. measurement period.

In harder sediments both halves of a small core section were used to make a sandwich around the probe. A groove was scraped in the face of one core half to accept the probe. The preparation of samples for this type of measurement was time-consuming and required use of part of the archive half of the core.

Conductivity is determined from the relation that applies for a line source in an infinite medium:

$$
K=\frac{A I^{2} \ln \left(t_{2} / t_{1}\right)}{T_{2}-T_{1}}-B,
$$

where $K=$ the thermal conductivity, $I=$ the current flowing in the heater wire, $t_{1}$ and $t_{2}$ are two times in the measurement period, $T_{2}$ and $T_{1}$ are temperatures at times $t_{2}$ and $t_{1}$, and $A$ and $B$ are constants. For the QTM device, $A$ and $B$ are determined empirically by comparison with known standards. For the needle probe device, $B=0$ and $A$ is determined directly from probe parameters.

\section{Correction Applied to Data}

All conductivity values have been corrected to conditions in situ in the hole by the relation

$$
K_{\text {in situ }}=k_{\text {lab }}\left(1-\frac{\left(T_{\text {lab }}-T_{\text {hole }}\right)}{400}\right) 1+\frac{D}{183,000},
$$

where $T$ is temperature and $D$ is depth.

QTM measurements are corrected for a difference between measured and stated values of the quartz glass standard. It was noted that when a 40 -s observation period was used, the measured values were consistently about 5 per cent higher than the stated value. The reasons for this discrepancy are discussed further in the chapter on geothermal observations (Langseth and others, this volume). We applied a correction factor to each QTM measurement. This correction factor is

$$
\frac{K_{\text {nominal }}}{K_{\text {measured }}},
$$

where $K_{\text {nominal }}$ is the stated conductivity of the quartz glass standard $\left(1.346 \mathrm{Wm}^{-1} \mathrm{~K}^{-1}\right)$ and $K_{\text {measured }}$ is the measured value on the quartz standard. Although the applicability of this correction can be questioned (Langseth and others, this volume), it has been applied to all data reported here.

\section{EXPLANATORY NOTES}

\section{Obtaining Samples}

Potential investigators who desire to obtain samples should refer to the DSDP-NSF Sample Distribution Policy. Samples request forms may be obtained from The Curator, Deep Sea Drilling Project, A-031, University of California, San Diego, La Jolla, California 92093. Requests must be as specific as possible; include site, core, section, interval within a section, and volume of sample required.

\section{Numbering of Sites, Holes, Cores, and Samples}

DSDP drill sites are numbered consecutively from the first site drilled by Glomar Challenger in 1968. Site numbers are slightly different from hole numbers. A site number refers to one or more holes drilled while the ship is positioned over one acoustic beacon. These holes may be located within a radius as great as 900 meters from the beacon. Several holes may be drilled at a single site by pulling the drill pipe above the sea floor out of one hole, moving the ship 100 meters or more, and drilling another hole. 
The first (or only) hole drilled at a site takes the site number. A letter suffix, in alphabetical order, distinguishes each additional hole at the same site. For example, the first hole takes only the site number; the second takes the site number with suffix $\mathrm{A}$; the third takes the site number with suffix B, and so forth. It is important, for sampling purposes, to distinguish among the holes drilled at a site, because sediments or rocks recovered from different holes usually do not come from equivalent positions in the stratigraphic column.

The cored interval is measured in meters below the sea floor. The depth of an individual core is determined by the depth below sea floor at which the coring operation began and that at which it ended. Each coring interval is generally 9.5 meters long, which is the nominal length of a core barrel; however, the coring interval may be shorter or (though rarely) longer. Cored intervals are not necessarily adjacent to each other, but may be separated by drilled intervals. In soft sediment, the drill string can be "washed ahead" with the core barrel in place but not recovering sediment by pumping water down the pipe at high pressure to wash the sediment out of the way of the bit and up the space between the drill pipe and wall of the hole; however, if thin hard rock layers are present, it is possible to get spotty sampling of these resistant layers within the washed interval and thus have a cored interval greater than 9.5 meters.

Cores taken from a hole are numbered serially from the top of the hole downward. Core numbers and their associated cored intervals in meters below the sea floor are normally unique for a hole; however, problems may arise if an interval is cored twice. When this occurs, the core number is assigned a suffix, such as "S,"'2 for "supplementary."

Full recovery for a single core is normally 9.28 meters of sediment or rock, which is in a plastic liner $(6.6-\mathrm{cm}$ inside diameter), plus about a 0.2 -meter-long sample (without a plastic liner) in the core catcher. The core catcher is a device at the bottom of the core barrel which prevents the cored sample from sliding out when the barrel is being retrieved from the hole. The sediment core, which is in the plastic liner, is then cut into 1.5 -meter-long sections and numbered serially from the top of the sediment core (Figure 6). When we obtain full recovery, the sections are numbered from 1 through 7 , with the last section sometimes less than 1.5 meters long. When the core is examined, the core catcher sample is placed below the last section, labeled core catcher (CC), and treated as a separate section.

When recovery is less than 100 per cent, and if the sediment rock is contiguous, the recovered sediment is placed in the top ${ }^{3}$ of the cored interval and 1.5-meterlong sections numbered serially, from top to bottom. There are as many sections as needed to accommodate the length of the core recovered (Figure 6); for example, 3 meters of core sample in plastic liners will be divided into two 1.5-meter-long sections. Sections are cut start-

\footnotetext{
${ }^{2}$ Note that this designation has been used on previous legs as a prefix to the core number for sidewall core samples.

${ }^{3}$ This technique differs from the labeling systems used on Legs 1 through 45 , which had a "zero section" but no "number 7 section."
}

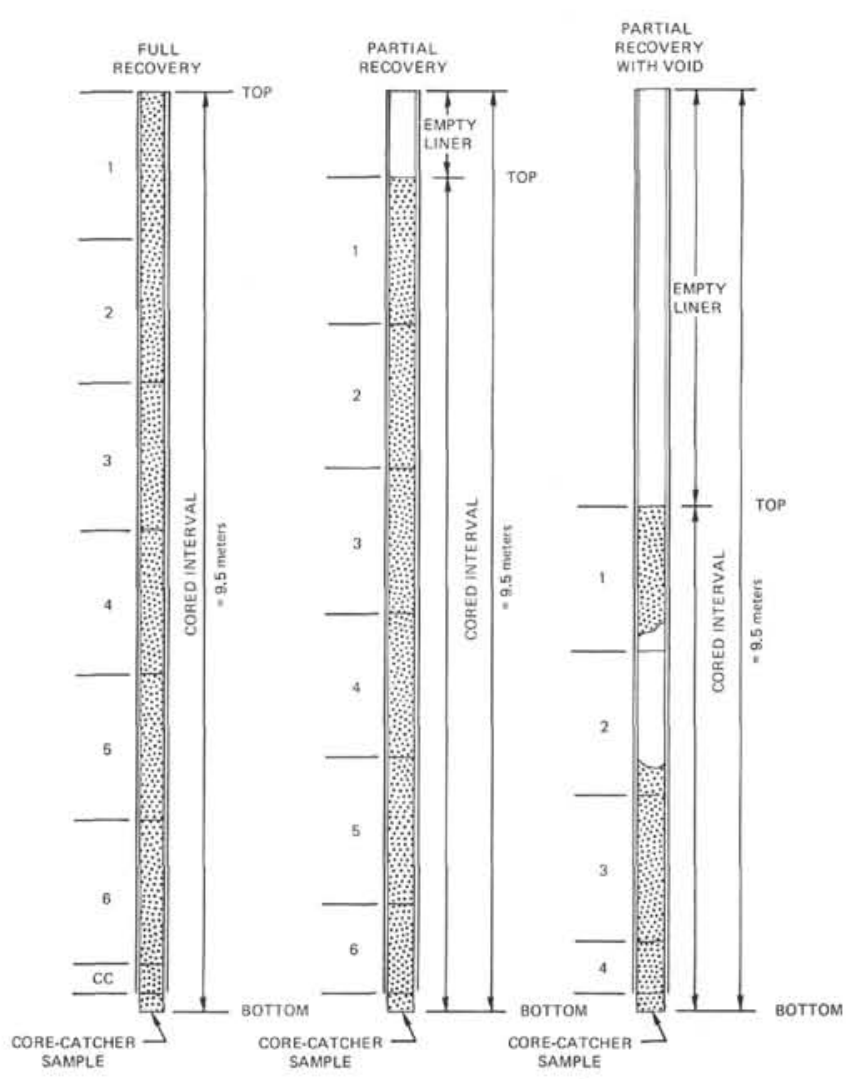

Figure 6. Diagram showing procedure in cutting and labeling of core sections.

ing at the top of the recovered sediment, and the last section may be shorter than the normal 1.5 meter.

When recovery is less than 100 per cent, the original stratigraphic position of the sediment in the cored interval is unknown, so we employ the convention of assigning the top of the sediment recovered to the top of the cored interval. This is done for convenience in data handling and for consistency. If recovery is less than 100 per cent and core fragments are separated, and if shipboard scientists believe the sediment was not contiguous, then sections are numbered serially and the intervening sections noted as void. The description of the core catcher sample follows that of the lowest section.

Samples within a section are designated by intervals in centimeters, calculated as the distance from the top of that particular section. A full identification number for a sample consists of the following information, in order: leg, site, hole, core number, and interval in centimeters from the top of section. For example, a sample identification number " $57-438 \mathrm{~B}-9-3,12-14 \mathrm{~cm}$ " is interpreted as follows: 12 to $14 \mathrm{~cm}$ designates a sample comprising the interval 12 to $14 \mathrm{~cm}$ from the top of Section 3 of Core 9, from the third hole drilled at Site 438 during Leg 57. A sample from the core catcher of this core is designated as " $57-438 \mathrm{~B}-9, \mathrm{CC}, 12-14 \mathrm{~cm}$."

The depth below the sea floor for a sample numbered " $57-438 \mathrm{~B}-9-3,12-14 \mathrm{~cm}$ " is the summation of the following: (1) the depth to the top of the cored interval for Core 9, which is 362 meters; (2) 3 meters for Sections 1 
and 2 (each 1.5 meters long); and (3) the $12-\mathrm{cm}$ depth from the top of Section 3. All of these variables add up to 365.12 meters, ${ }^{4}$ which theoretically is the sample depth below the sea floor.

\section{Handling of Cores}

A core is normally cut into 1.5 -meter sections, sealed, and labeled. Then the sections are brought into the core laboratory for processing. The following determinations are made before the sections are split: gas analysis, thermal conductivity analysis (soft sediment only), and continuous wet-bulk density determinations, using the Gamma Ray Attenuation Porosity Evaluation (GRAPE).

The cores are then split longitudinally into "working", and "archive" halves. Samples are extracted from the "working" half, including those for determination of grain-size distribution, mineralogy by X-ray diffraction, sonic velocity by the Hamilton Frame method, wet-bulk density by a static GRAPE technique, water content by gravimetric analysis, carbon-carbonate analysis, percentage calcium carbonate (Karbonate Bomb), geochemical analysis, paleontological studies, and others.

Smear slides from each major lithology and most minor lithologies are prepared and examined microscopically. The archive half is then described and photographed. Physical disturbance by the drill bit, color, texture (for uncemented lithologies), sedimentary structure, and composition ( \pm 20 per cent) of the various lithologies are noted on standard core description sheets.

After the cores are sampled and described, they are maintained in cold storage aboard Glomar Challenger until they can be transferred to the DSDP repository. Core sections which are removed for organic geochemistry study are frozen immediately onboard ship and kept frozen. All Legs 56 and 57 cores and frozen cores are presently stored at the DSDP West Coast Repository (Scripps Institution of Oceanography).

Core descriptions, smear slide descriptions, carbonate bomb determinations (percentage $\mathrm{CaCO}_{3}$ ) -all determined aboard ship - grain-size analyses, and carbon-carbonate determinations-determined at the DSDP shore-based laboratory-serve as the data for the Visual Core Descriptions in this volume. These samples and their locations in the core are coded with a symbol on the core description sheets. The key to these codes is in Figure 7.

\section{Visual Descriptions}

\section{Sediment Disturbance}

Recovered rocks, and particularly the soft sediments, may be extremely disturbed. Mechanical disturbance is the result of coring technique, which uses a large $(25-\mathrm{cm}$ diameter) bit with a small $(6.0-\mathrm{cm}$ diameter) opening for the core sample. The following disturbance categories are used for soft and firm sediment. These categories

\footnotetext{
${ }^{4}$ Sample requests should refer to a specific interval within a core section rather than to depth below sea floor.
}

will be indicated on the core description sheet (in a column) by coded patterns to which the key is in Figure 5 . The categories are as follows: (1) slightly deformed: bedding contacts are slightly bent; (2) moderately deformed: bedding contacts have undergone extreme bowing; (3) very deformed: bedding is completely disturbed, sometimes showing symmetrical diaper-like structure; and (4) soupy: water-saturated intervals which have lost all aspects of original bedding.

\section{Sedimentary Structures}

In the soft, and even in some hard, sedimentary cores, it may be extremely difficult to distinguish between natural structures and structures created by the coring process. Thus the description of sedimentary structures is optional. A column on the Core Description Sheet (Figure 7) may have patterns (coded symbols) to indicate typical structures. The key to the set of structure symbol codes is in Figure 8.

\section{Color}

Colors of the geologic material are determined with a Munsell or Geological Society of America Rock-Color Chart. Colors are determined immediately after the cores are split and still wet.

\section{Graphic Lithology Column}

A graphic lithologic column is presented, based on a lithologic classification scheme. The lithologies and their corresponding symbols are in Figure 9. Often a single lithology will be represented by a single pattern. Some lithologies are represented by a grouping of two or more symbols. The symbols in this grouping may correspond to end member sediment constituents, such as clay and nannofossil ooze. Normally the symbol for the dominant constituent is placed on the right-hand side of the column and the symbol for the subordinate constituent on the left-hand side. Component percentages may be indicated by presenting the symbols themselves in proportion to their percentages. For example, the left 20 per cent of a column may show a clay symbol and the right 80 per cent of the column a nannofossil ooze symbol. This means that the sample contained approximately 80 per cent nannofossils and 20 per cent clay. The vertical lines which separate the symbols are shown in Figure 9 with their corresponding percentages and positions in the column.

Because of the difference in the length-to-width ratio between the actual sediment core and the graphic lithologic column, it is not possible to reproduce structures as they appear in the core. They become highly flattened and distorted. The same is true for erratic pebbles and changes of lithology in the cores.

\section{Text of Core Description}

Format, style, and terminology of the descriptive portion of the Core Description Sheets (Figure 7) are not controlled by the Mandatory Graphic Lithologic Column Scheme beyond the minimal name assignment which is derived from the lithologic classification. Colors and additional information such as structure and 
M. A. ARTHUR, C. G. ADELSECK, JR.

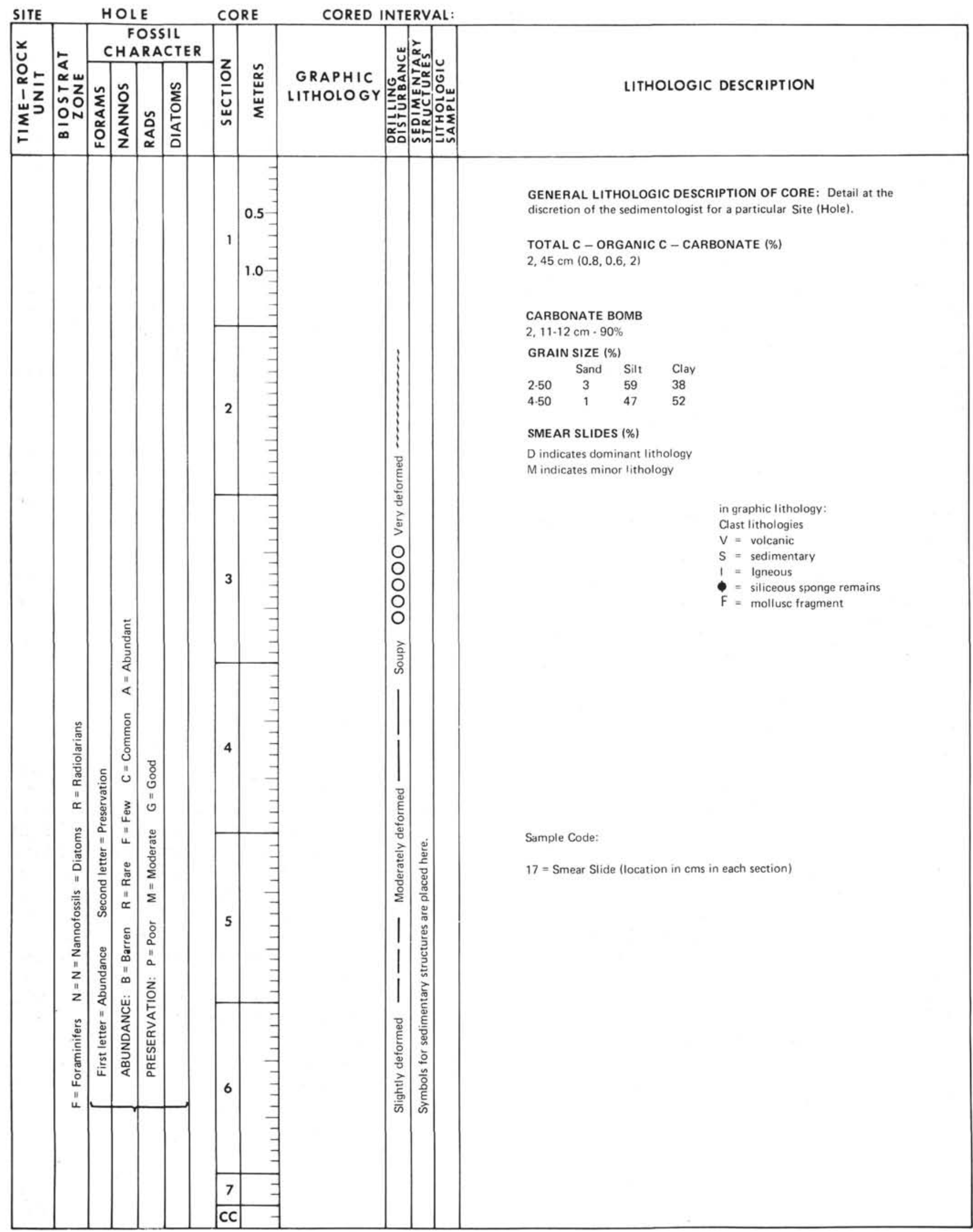

Figure 7. Typical core description sheet with sediment deformation symbols, sample codes, and other general information. 


Sedimentary
Structure

Figure 8. Key to sedimentary structure symbols.

textures are normally included in the text portion of the core description.

\section{Carbonate Bomb}

Percentage $\mathrm{CaCO}_{3}$ was also determined onboard ship by the Karbonate Bomb technique (Müller and Gastner, 1971). In this simple procedure, a sample is powdered and treated with $\mathrm{HCl}$ in a closed cylinder. Any resulting $\mathrm{CO}_{2}$ pressure is proportional to the $\mathrm{CaCO}_{3}$ content of the sample. Application of the calibration factor to the manometer reading $(\times 100)$ yields percentage $\mathrm{CaCO}_{3}$. Percentage of error can be as low as 1 per cent for sediments high in $\mathrm{CaCO}_{3}$, and in general an accuracy of \pm 2 to \pm 5 per cent can be obtained.

These data presented on the Core Form. The sample interval is designated by two numbers: the section number, followed by the top of the sample interval; for example, a sample from Section 2, 11 to $12 \mathrm{~cm}$, with 90 per cent calcium carbonate will present on the core form as follows:

$$
\begin{gathered}
\text { CARBONATE BOMB } \\
2,11-12 \mathrm{~cm}=90 \%
\end{gathered}
$$

\section{Carbon-Carbonate Analysis}

Following the cruise, sediment samples are analyzed at the DSDP sediment laboratory on a LECO WR-12 Carbon Analyzer. Sample preparation procedures are identical to those with the old LECO 70 Analyzer out- lined in Boyce and Bode (1973). Discussions of the LECO WR-12 Analyzer are in Bode (in press). Accuracy and precision of the results as follows:

$$
\begin{aligned}
\text { Total carbon } & = \pm 0.3 \text { per cent (absolute) } \\
\text { Organic carbon } & = \pm 0.06 \text { per cent (absolute) } \\
\mathrm{CaCO}_{3} & = \pm 3 \text { per cent (absolute) }
\end{aligned}
$$

The carbon-carbonate data are presented on the Core Forms. The sample interval is designated by two numbers: the section number, followed by the top of the sample interval; for example, a sample from Section 2 at $45 \mathrm{~cm}$ with 0.8 per cent total carbon, 0.6 per cent organic carbon, and 2 per cent calcium carbonate will be presented on the Core Forms as follows:

TOTAL: ORGANIC: CARBONATE (per cent)

$$
2,45 \mathrm{~cm}(0.8,0.6,2)
$$

\section{Grain-Size Analysis}

Distribution of sand-size, silt-size, and clay-size particles was determined from 10 -cc sediment samples at the DSDP sediment laboratory by standard sieve and pipette methods (Initial Reports, Appendix III, Volume 4 , p. 745 , with modified settling times as in Boyce, 1972). The sand, silt, and clay boundaries are based on the Wentworth (1922) scale. Thus the particle size of the sand, silt, and clay fractions ranges from 2000 to 62.5 $\mu \mathrm{m}$, and less than $3.91 \mu \mathrm{m}$, respectively.

Grain-size data are presented on the Core Forms. The sample interval is designated by two numbers: the section number and the top of the sample interval within that section; for example, a sample from Section 2, 11 to $13 \mathrm{~cm}$ with a grain-size distribution of 20 per cent sand-size, 30 per cent silt-size, and 50 per cent clay-size will be presented on the Core Forms as follows:

$\begin{array}{ll}\text { SMEAR SLIDE SUMMARY } \\ & 2-11 \\ \text { Sand } & 20 \\ \text { Silt } & 30 \\ \text { Clay } & 50 \\ \text { etc. } & \text { etc. }\end{array}$

\section{REFERENCES}

Bennett, R. H., and Keller, G., 1973. Physical properties evaluation. In van Andel, T. H., Heath, G. R., et al, Init. Repts. DSDP, 16: Washington (U.S. Govt. Printing Office), 513-519.

Blow, W. H., 1969. Late middle Eocene to Recent planktonic foraminiferal biostratigraphy. In Brönniman, P., and Renz, H. H. (Eds.), Proceedings of the First International Conference on Planktonic Microfossils: Leiden (E. J. Brill), pp. 199-421.

Bode, G. W., 1973. Carbon and carbonate analyses-Leg 18. In Kulm, L. D., von Huene, R., et al., Init. Repts. DSDP, 18: Washington (U.S. Govt. Printing Office), 1069-1076.

Boyce, R. E., 1976. Definitions and laboratory techniques of compressional sound velocity parameters and wet-water content, wet bulk density, and porosity parameters by gravimetric and gamma ray attenuation techniques. In Schlanger, S. D., Jackson, E. D., et al., Init. Repts. DSDP, 33: Washington (U.S. Govt. Printing Office), 931-935.

Boyce, R. E., and Bode, G. W., 1972. Carbon and carbonate analyses, Leg 9. In Hays, J. D., et al., Init. Repts. DSDP, 9: Washington (U.S. Govt. Printing Office), 797-816. 
Bukry, D., 1975. Coccolith and silicoflagellate stratigraphy, northwestern Pacific Oceans. In Larson, R. L., Moberly, R., et al., Init. Repts. DSDP, 32: Washington (U.S. Govt. Printing Office), 677-701.

Dickinson, W. R., and Seely, D. R., 1979. Structure and stratigraphy of forearc regions. Am. Assoc. Petrol. Geol. Bull., 63, 2-31.

Foreman, H. P., 1975. Radiolaria from the North Pacific, Deep Sea Drilling Project, Leg 32. In Larson, R. L., Moberly, R., et al., Init. Repts. DSDP, 32: Washington (U.S. Govt. Printing Office), 579-676.

Gartner, S., 1977. Calcareous nannofossil biostratigraphy and revised zonation of the Pleistocene. Mar. Micropaleont., 2, $1-25$.

Gealy, E. L., Winterer, E. L., and Moberly R., 1971. Methods, conventions and general observations. In Winterer, E. L., et al., Init. Repts. DSDP, 7, Pt. 2: Washington (U.S. Govt. Printing Office), 9-26.

Honza, E. (Ed.), 1977. Geological investigation of Japan and Southern Kurile Trench and slope areas. G H-72-6 Cruise. Geol. Surv. Jpn. Cruise Rept. No. 7., 1-127.

Ikebe, N., Takayanagi, Y., Chiji, M., and Chinzei, K., 1972. Neogene biostratigraphy and radiometric time scale of Japan-an attempt at intercontinental correlation. Pac. Geol., 4, 39-78.

Ishiwada, Y., and Ogawa, K., 1976. Petroleum geology of offshore water around the Japanese Islands: United Nations ESCAP, CCOP, Tech Bull., 10, 23-34.

Karig, D. E., and Sharman, G. F., 1975. Subduction and accretion in trenches. Geol. Soc. Amer. Bull., 86, 377-389.

Koizumi, I., 1975. Late Cenozoic diatom biostratigraphy in the circum-North Pacific. J.Geol. Soc. Jpn., 81, 611-627.

LaBrecque, J. L., Kent, D. V., and Cande, S. C., 1977. Revised magnetic polarity time scale for Late Cretaceous and Cenozoic time. Geology, 5, 330-335.

Lancelot, Y., 1971. Chert and silica diagenesis in sediments from the Central Pacific. In Winterer, E. L., Ewing, J. I., et al., Init. Repts. DSDP, 17: Washington (U.S. Govt. Printing Office), 377-406

Langseth, M., Okada, H., et al., 1978. Near the Japan Trench -transects begun. Geotimes, 23, 22-26.

Lee, H. J., Olsen, H. W., and von Huene, R., 1973. Physical properties of deformed sediments from Site 181. In Kulm,
L. P., von Huene, R., et al., Init. Repts. DSDP, 18: Washington (U.S. Govt. Printing Office), 897-901.

Maiya, S., Tsunemassa, S., and Tomindo, S., 1976. Late Cenozoic planktonic foraminiferal biostratigraphy of northwest Pacific sedimentary sequences. In Takayanagi, Y., and Saito, T. (Eds.), Progress in Paleontology: New York (Micropaleontology Press), pp. 395-421.

Minster, J. B., Jordan, T. H., Molnar, P., and Haines, E., 1974. Numerical modelling of instantaneous plate tectonics. Geophys. J. Roy. Astron. Soc., 36, 541-576.

Moore, J. C., and Karig, D. E., 1976. Sedimentology, structural geology, and tectonics of the Shikoku subduction zone, Southwestern Japan. Bull. Am. Geol. Soc., 87, 12591268.

Müller, G., and Gastner, M., 1971. The "Karbonate Bomb," a simple device for determination of the carbonate content in sediments, soils, and other materials. Neues Jahrb. Mineral. Monatsh., 10, 466-469

Nasu, N., and Kobayashi, K. (Eds.), 1980. Preliminary Report of the Hakuho Maru Cruise KH-77-1 (IPOD Site Survey). Ocean Research Institute, University of Tokyo.

Oda, M., 1977. Planktonic foraminiferal biostratigraphy of the Late Cenozoic sedimentary sequence, Central Honshu, Japan. Sci. Rep. Tohoku Univ., 2nd Ser. (Geol), 48, 1-72.

Riedel, W. R., and Sanfilippo, A., 1977. Cainozoic Radiolaria. In Ramsay, A. T. S. (Ed.), Oceanic Micropaleantology: Cambridge (Cambridge University Press), pp. 847-912.

Saito, T., 1977. Late Cenozoic planktonic foraminiferal datum levels: The present state of knowledge toward accomplishing pan-Pacific stratigraphic correlation. In Saito, T., and Ujiie, H. (Eds), Proceedings of the First International Congress on Pacific Neogene Stratigraphy, Tokyo, 1976: Tokyo (Kaiyo Shuppan), pp. 61-80.

Shepard, F. P., 1954. Nomenclature based on sand-silt-clay ratios. J. Sediment Petrol., 24, 151-158.

von Huene, R., Nasu, N., et al., 1978. On Leg 57 Japan Trench transected. Geotimes, 23 (No. 4), 16-21.

Wentworth, C. K., 1922. A scale of grade and class terms of clastic sediments. J. Geol., 30, 377.

Wentworth, C. K., and Williams, H., 1932. The classification and terminology of the pyroclastic rocks. Bull. Nat. Res. Counc. 89, 19-53. 
Pelagic

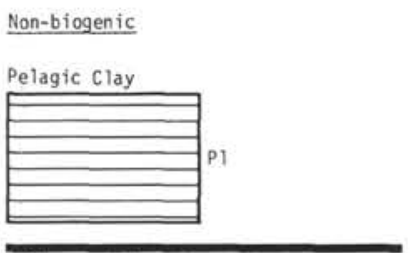

Siliceous Biogenic

Pelagic Siliceous Biogenic - Soft

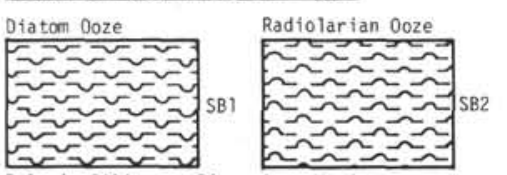

Vertical bar percent

(5) Designation

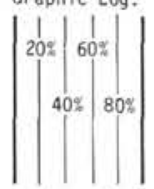

Diatom-Rad or

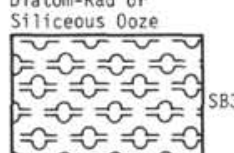

Pelagic Siliceous Biogenic - Hard

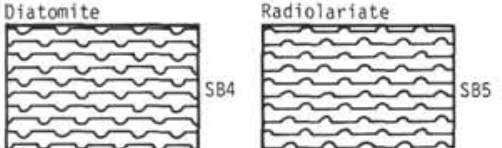

Iransitional Biogenic siliceous Sediments
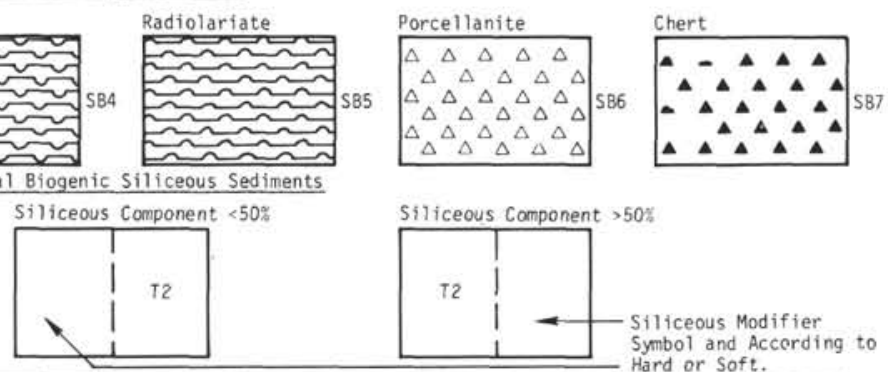

Siliceous Component $>50^{\circ}$

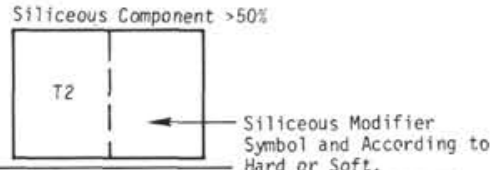

Calcareous Biogenic
Pelagic Biogenic Calcareous - Soft

Nannofossil 0oze

Pelagic Biogenic Calcareous - Hard

Limestone

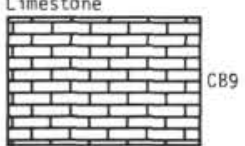

Nanno-Foram or

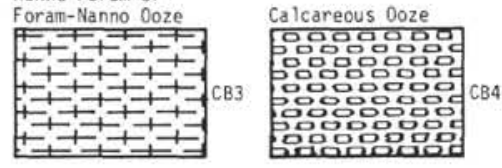

Nanno-Foram or

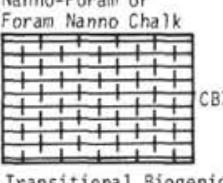

Trasitional biogenic Caicareous sediments
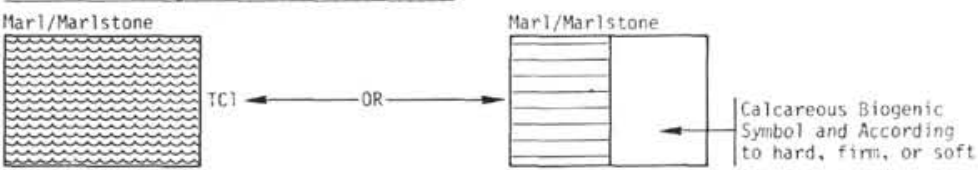
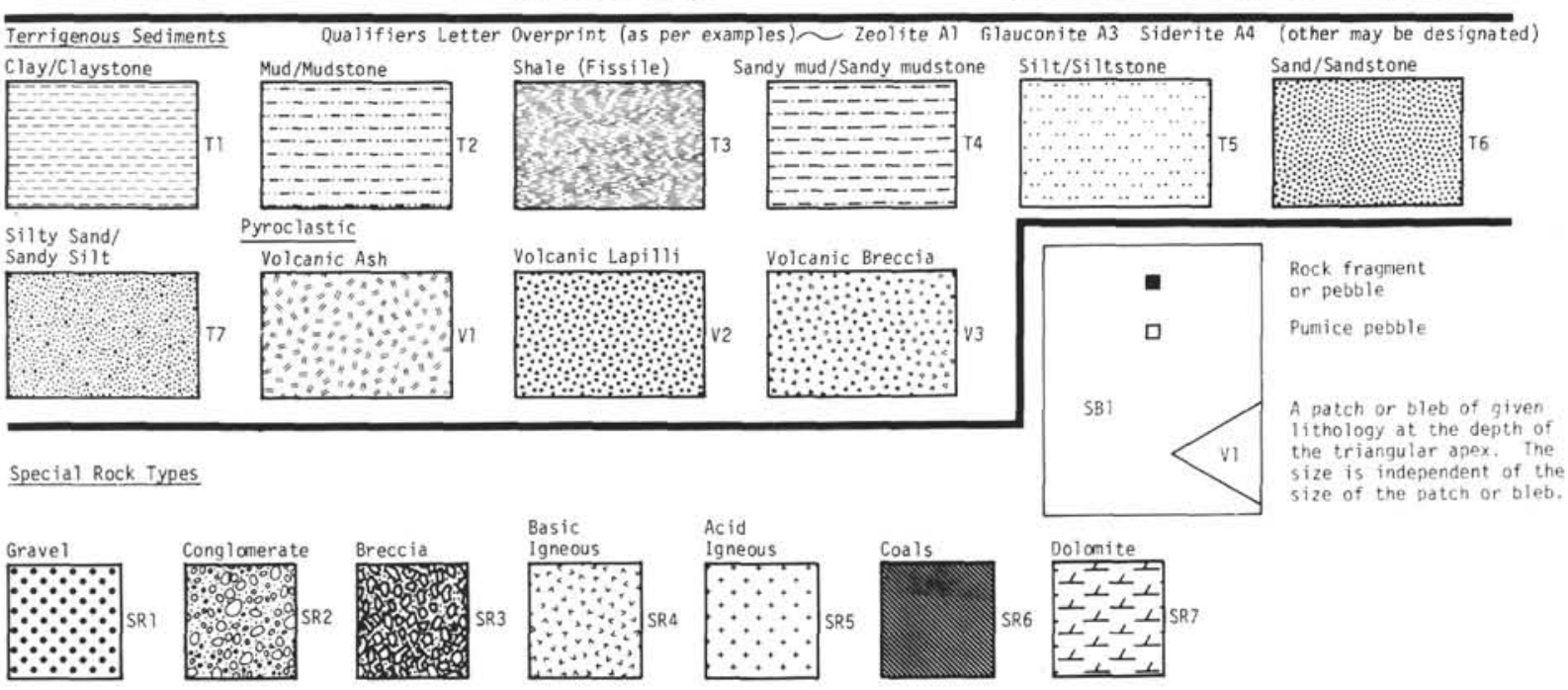

Figure 9. Graphic symbols corresponding to the lithologic classification. 